\title{
Isolation of Catechin and Gallic Acid from Colombian Bark of Pinus patula
}

Rodrigo A Sarria-Villa ${ }^{1 *}$, José A Gallo-Corredor ${ }^{1}$ and Martha Isabel Páez ${ }^{2}$

${ }^{1}$ Department of Chemistry, University of Cauca, GIQA, Calle 5 No. 4-70, Popayán, Colombia

${ }^{2}$ Department of Chemistry, University of Valle, GICAMP, Calle 13 No. 100-00, Cali, Colombia

\begin{abstract}
Pine bark is a rich source of natural polyphenols, compounds which have attracted increasing attention in the fields of nutrition, health and medicine. Extractive components include large amounts of phenolic compounds. The ethanolic extract was obtained from Pinus patula bark grown in the forests of the Cauca Department in Colombia South America. The Gallic acid, catechin, epicatechin and procyanidin B2 contents in ethanolic extract were 3.12, 1.99, 0.80, and $0.71 \%$, respectively, these compounds were determined using HPLC with UV-Vis detection. Ethanolic extract was divided using column chromatography to obtain an ethanol-soluble fraction with tannins and phlobaphenes as well as an ethanol-insoluble fraction mainly composed of Phenolic acids. Catechin and Gallic acid finally isolated were characterized using UV-Vis, IR, NMR, ${ }^{13} \mathrm{C},{ }^{1} \mathrm{H}, \mathrm{HSQC}, \mathrm{HMBC}$ and GC-MS spectrometry.
\end{abstract}

Keywords: Catechin; Gallic acid; Pinus; Phenolic compounds

\section{Introduction}

Pine bark is rich in phenolic compounds. The main phenolic compounds found in pine bark are catechin/epicatechin, epigallocatechin and epicatechin gallate [1]. Possible applications for pine bark are antiradical, antioxidant and anti-inflammatory properties and are marketed as food supplement and an herbalbased medication. Tannins from pine bark have been used to make wood adhesives and foams [2]. Pine bark is mainly composed of polysaccharides (cellulose and hemicellulose) and lignin, as well as minerals such as oxalates, phosphates, silicates, boron, copper, and manganese [3]. Extractive components are divided into lipophilic and hydrophilic substances. Lipophilic substances include fats, waxes, terpenes, terpenoids, and higher aliphatic alcohols. The hydrophilic fraction includes substances that are extractable by water or organic solvents and contains large amounts of phenolic constituents such as tannins, monomeric flavonoids such as quercetin and hydroquercetin, and a lesser quantity of soluble carbohydrates, proteins, and vitamins. Some pine species have produced aqueous extraction yields of $13.3 \%$ for $P$. radiata [4] and $4.1 \%$ for $P$. contorta, ethanol extraction yields of $11.6 \%$ for $P$. echinata [5], and acetone extraction yields ranging from $8.8 \%$ to $50 \%$ for P. loblolly [6]. It has also been reported that the use of $80 \%$ aqueous ethanol to obtain the extract of $P$. durangensis yielded $16.15 \%$, lower than the $18.7 \%$ yield obtained using $70 \%$ aqueous acetone [7]. In studies by Pan, up to twenty-six phenolic compounds have been found in the bark of Pinus sylvestris from Sweden, with catechins and procyanidins being the most abundant [8]. Phenolic compounds extracted from pine bark include Gallic acid, ferulic and p-hydroxybenzoic acids, monomers such as catechin, epicatechin and taxifolin, and condensed flavonoids such as procyanidins [9]. The chemical composition of tannins has been determined thanks to the development of techniques such as gas chromatography, high performance liquid chromatography, thin layer chromatography, infrared spectroscopy, mass spectrometry, and nuclear magnetic resonance [10]. In this way, studies have been conducted on tannins extracted from the bark of species such as Pinus radiata [11], Pinus pinaster and Pinus radiata [12], Pinus pinaster and Pinus massoniana [13], maritime pine [1], Acacia mangium [14], and Acacia confusa [15]. The composition of tannins in Pinus brutia bark has been studied using MALDI-TOF MS and ${ }^{13} \mathrm{C}$ NMR spectroscopy [16]. It is well known that phenolic compounds present antifungal, antibiotic, antioxidant, and allelopathic effects, among others [17]. These compounds have earned a reputation for their activity in plants, in defense against insect attacks and in microbial diseases. It is believed that procyanidins can protect from cardiovascular diseases $[18,19]$. Pinus bark has shown to have antioxidant, anticarcinogenic, antimutagenic, antimicrobial, antiinflammatory, and cardio-cerebrovascular protective effects, among others $[9,20]$. Phenolic compounds such as catechin have applications in the prevention of food oxidation, astringency, reactions with metals and proteins, and the synthesis of derivatives for pharmaceutical applications, as well as antibacterial activity and different medicinal benefits (cholesterol-lowering and antiallergic effects, etc.). Gallic acid is used in the production of antioxidants in the food industry, in brewing, in the pharmaceutical industry for the synthesis of mescaline and trimethoprim, in photography, and in papermaking, among others [17]. In the Cauca-Colombia department there are more than 14 thousand hectares planted with pine. Forest residues generated in the field can be used to obtain products with different applications. This study considers the identification of phenolic compounds present in Pinus patula bark and the isolation and spectroscopic identification of catechin and Gallic acid present in the ethanol extracts obtained.

\section{Materials and Methods}

\section{Samples}

Samples of P. patula bark were collected from Smurfit Carton de Colombia forest sub nucleus (Cabuyerita) located in the northwest of Popayan city in the Cauca department (Colombia), latitude $1^{\circ} 56^{\prime}$ north, longitude $77^{\circ} 10^{\prime}$ west, and altitude $1700 \mathrm{~m}$. The trees' diameters ranged from 25 to $30 \mathrm{~cm}$ and were 16 years old. The barks were airdried and ground in a mill and sieve to select particles smaller than 1 $\mathrm{mm}$.

*Corresponding author: Rodrigo A Sarria-Villa, Faculty of Natural, Exact and Educational Sciences, Department of Chemistry, University of Cauca, GIQA, Calle 5 No. 4-70, Popayán, Colombia, Tel: +5728209800; E-mail: rodrigosv@unicauca.edu.co

Received October 31, 2017; Accepted November 10, 2017; Published November 15, 2017

Citation: Sarria-Villa RA, Gallo-Corredor JA, Páez MI (2017) Isolation of Catechin and Gallic Acid from Colombian Bark of Pinus patula. Chem Sci J 8: 174. doi: 10.4172/2150-3494.1000174

Copyright: @ 2017 Sarria-Villa RA, et al. This is an open-access article distributed under the terms of the Creative Commons Attribution License, which permits unrestricted use, distribution, and reproduction in any medium, provided the original author and source are credited. 


\section{Chemicals}

Procyanidin B2 (98\%) Catechin (98\%) and Epicatechin (98\%) were supplied by Sigma. Ethyl acetate (99.8\%), n-Hexane (96\%) were supplied by Merck, EM Science. Absolute Ethanol (99.8\%) was by ACS, Riedel-de Haen. Sephadex G-25 was by Pharmacia Biotech. Acetonitrile, HPLC, Purity $99.9 \%$ and acetone reactive grade were by Mallinckrodt. Deuterated- $\mathrm{d}_{6}$ acetone $(99.9 \%$ atom $\% \mathrm{D})$ was by Aldrich. Methanol (99\%) was by Fisher Scientific.

\section{Extraction and characterization of phenolic compounds}

An ethanol-water solvent mixture (30:70) was used for the leaching extraction of phenolic compounds. The extract obtained was used to identify phenolic compounds and to separate the analytes of interest [21]. The hydroalcoholic extract obtained was roto evaporated at $55^{\circ} \mathrm{C}$ until the solvent was completely removed [22]. The composition of the hydroalcoholic extract was determined by high performance liquid chromatography (HPLC), and the phenolic compounds of interest were isolated by column chromatography [23].

Identification of the phenolic compounds present in the hydro alcoholic extract of Pinus patula bark by HPLC

Using standard solutions, identification and quantification of gallic acid, catechin, epicatechin, and procyanidin B2 was carried out in Pinus patula bark extracts using a liquid chromatograph Water 1515 with UV detection [24]. The chromatographic conditions used allowed the identification of phenolic compounds. A $150 \times 3.9 \mathrm{~mm} \mu$-Bondapak $\mathrm{C}_{18}$ column was used, with a flow of $1.0 \mathrm{~mL} / \mathrm{min}$, isocratic elution, and a mobile phase composed of $0.5 \%$ methanol in $0.01 \mathrm{M}$ Acetic acid-acetonitrile (96.5\%-3.5\%). UV detection at $280 \mathrm{~nm}$ and room temperature were used. Validation of the chromatographic method was performed to determine parameters such as linearity, precision, accuracy, and sensitivity. Solid-phase extraction was used prior to HPLC [25]. The Robards method [26] was used to eliminate matrix interference using solid-phase extraction. The percent recovery of these compounds (gallic acid, catechin, epicatechin and procyanidin B2) was determined after solid phase extraction (SPE).

\section{Column separation of phenolic compounds}

The hydroalcoholic extract was divided into an ethanolsoluble fraction and an ethanol-insoluble fraction [22]. Column chromatography was performed (Silica, Sephadex and $\mathrm{C}_{18}$ ) for these fractions with methanol, acetone and hexane, collecting $5 \mathrm{~mL}$ volumes in different tubes. This process was followed by TLC on silica gel using, as eluent, toluene-acetone-formic acid (3:6:1), and the plates were developed with UV light ( $254 \mathrm{~nm}$ and $365 \mathrm{~nm}$ ), vanillin, iron chloride and an iodine chamber to establish the composition of the fractions. In TLC, standards of catechin and Gallic acid were also used (gallic acid, Rf 0.88; catechin, Rf 0.86) [27].

\section{Obtention of ethanol-soluble fraction}

The hydroalcoholic fraction was extracted with water and further separated into two fractions: a soluble fraction (crude tannin, fraction $\mathrm{T}_{1}$ ) and an insoluble fraction (crude phlobaphenes, fraction $\mathrm{F}_{1}$ ). Crude tannin was washed successively with ethyl ether a number of times, sufficient to obtain spots only near the origin of the chromatogram using two-dimensional paper chromatography. [Paper chromatography (Whatman 3, $37 \mathrm{~cm} \times 47 \mathrm{~cm}$ ); eluent in the first direction: n-butanolAcetic acid-water (3:1:1); eluent in the second direction: $15 \%(\mathrm{w} / \mathrm{v})$ aqueous Acetic acid; developers: iron chloride, ultraviolet light, and iodine vapor]. Crude tannin $\left(\mathrm{T}_{1}\right)$ was washed with ether and ethyl acetate (fraction $\mathrm{T}_{2}$ ) and passed through a Sephadex G-25 column (30 $\mathrm{cm} \times 2 \mathrm{~cm}$ ), eluting with methanol followed by methanol-ethyl acetate 1:1 (v/v). TLC was performed on the fractions obtained with tolueneacetone-formic acid (3:6:1), and the plates were developed with ferric chloride, a UV lamp, vanillin, and iodine vapor. Crude phlobaphenes (fraction $\mathrm{F}_{1}$ ) were also washed with ethyl ether and ethyl acetate. The fraction was roto evaporated, and an infrared spectrum was taken from this fraction [22].

\section{Obtention of ethanol-insoluble fraction}

The ethanol-insoluble fraction was extracted with a $1 \%(\mathrm{w} / \mathrm{v})$ aqueous solution of $\mathrm{NaOH}$ at reflux temperature for 4 hours. The soluble fraction mainly corresponds to an aqueous solution of the sodium salt of Phenolic acids, which were then separated by precipitation with a concentrated $\mathrm{HCl}$ solution (fraction $\mathrm{AF}_{1}$ ) [22]. The insoluble fraction of the $\mathrm{NaOH}$ extraction corresponds to lignocellulosic material (Fraction LC). This material, after being washed with $5 \%$ Acetic acid and water, was treated with $72 \%$ sulfuric acid for 2 hours at $20^{\circ} \mathrm{C}$, diluted with water to a total volume of $575 \mathrm{~mL}$, and then refluxed for 4 hours. The solid was decanted and filtered on a weighed Gooch crucible, washed thoroughly with water, and vacuum dried at $55^{\circ} \mathrm{C}$ to constant weight. The melting point and solubility in solvents such as water, acetonitrile, dichloromethane, acetone, and methanol were determined for all the compounds obtained from the different fractions.

\section{Spectrometric characterization of gallic acid and catechin}

The separated compounds were characterized by IR, UV-VIS, and NMR spectroscopy using an Infrared FT-IR 8400 (Shimadzu), spectrophotometer UV-Vis (Spectronic 21) and NMR, Brucker Ultra shield Advance II $400 \mathrm{MHz}$ respectively. Correlation spectroscopy of nuclear magnetic resonance (NMR) such as heteronuclear singlequantum coherence spectroscopy (HSQC) and heteronuclear multiple-bond coherence spectroscopy (HMBC) also were used. Mass spectrometer GC-MS (Shimadzu QP 2010) was also used for structure elucidation.

\section{Results and Discussion}

\section{Extraction of phenolic compounds}

The extraction conditions for the extraction of phenolic compounds from Pinus patula bark were applied for $6 \mathrm{~h}$, with a particle size of less than $1.18 \mathrm{~mm}$, a temperature of $60^{\circ} \mathrm{C}$, a $30: 70 \%$ (water: ethanol) solvent ratio, a ratio of bark to solvent of $1-10 \mathrm{~g}-\mathrm{mL}$, and stirring at $250 \mathrm{rpm}$ [25]. Studies conducted in Cuba have reported bark extract yields of $8.29 \%$ for $P$. caribaea and of $10.19 \%$ for P. cubensis [28]. The use of ethanol (50\%) to do extraction of phenolic compounds yielded $6.66 \%$ for $P$. engelmannii and $19.4 \%$ for $P$. ayacahuite. These observations indicate that the extraction performance obtained with $50 \%$ ethanol is double or more than that obtained with water $[29,30]$.

\section{Separation and identification of phenolic compounds by chromatography}

The identification of gallic acid, catechin, epicatechin, and procyanidin B2 was performed according to the method by Romani et al. [24]. The most widely used analytical technique for the identification of flavonoids is reverse phase HPLC. However, the resolution of condensed phenolic compounds is possible up to the tetramer level [31]. Generally, phenolic compounds are chromatographed on $\mathrm{C}_{18}$ sorbents [32]. $\mathrm{C}_{18}$ columns are generally used in the analysis of pine extracts, wine, and 
grape tissue because lower retention times are obtained; on the other hand, $\mathrm{C}_{6}$ columns are typically used for the analysis of apple tissue, juice, and cider. Isocratic and gradient separations were performed; gradients usually start with a large percentage of the aqueous phase (usually $80-100 \%$ ), and methanol, acetonitrile, and Acetic acid are commonly used as the organic component of the eluents. The eluent should contain an acid to suppress the ionization of Phenolic acids, and methanol or acetonitrile are commonly used as the organic component of the eluent. Tetrahydrofuran is used for the analysis of hawthorn procyanidins [33]. Figure 1 shows the chromatogram of a mixture of gallic acid, catechin, epicatechin, and procyanidin B2 standards under the established optimum chromatographic conditions.

It can be observed that Gallic acid elutes first, followed by catechin, a monomeric flavonoid. It is observed that procyanidin B2 elutes before epicatechin, although procyanidin B2 is a dimeric flavonoid and epicatechin a monomeric one; this is not the case when using polar stationary phases such as silica (normal phase), where the phenolic compounds are eluted in order of increasing molecular weight. The retention times of these compounds are determined largely by the substitution on the phenyl group attached to the benzopyrone ring and the overall polarity of the molecule. The (-)-epicatechin and its oligomers elute later than those derived from (+)-catechin [34]. The elution order of the dimeric and trimeric procyanidins $\left(\mathrm{C}_{1}\right.$ and $\left.\mathrm{C}_{2}\right)$ remains surprisingly constant, regardless of the acid eluent and stationary phase used. On the other hand, the retention times of procyanidins $\mathrm{B} 1, \mathrm{~B} 4$, and $\mathrm{C} 1$ are the most affected by changes in the chromatographic system compared to the rest of the procyanidins [34]. Similarly, the chromatographic behavior of procyanidins is also affected by the concentration of the injected sample. When high amounts of the procyanidin fraction were added to a $\mathrm{C}_{18}$ column, their peaks in the elution profile shifted to lower retention times. This effect, caused by high concentrations, is reversible and may be due to the formation of polar complexes of small oligomers between themselves or with high molecular weight compounds [2]. Retention time of each of the compounds in the mixture of standards was determined and their percent relative standard deviation (\%RSD) was calculated. Retention times (in minutes, with \%RSD) were determined to be 3.231 (0.552\%), 10.057 (0.984\%), 17.653 (0.727\%), and 19.828 $(0.646 \%)$ for Gallic acid, catechin, procyanidin B2 and epicatechin, respectively. Under the established chromatographic conditions, a curve from 10 to $100 \mathrm{ppm}$ was prepared for each compound, which showed coefficients of determination of $0.999,0.993,0.997$, and 0.995 for gallic acid, catechin, epicatechin, and procyanidin B2, respectively. To determine the limits of detection and quantification, curves from 1 to $10 \mathrm{ppm}$ were generated. Detection and quantification limits of 0.065 and 0.217, 0.071 and 0.236, 0.114 and 0.381, and 0.090 and $0.299 \mathrm{ppm}$ was obtained for gallic acid, catechin, epicatechin and procyanidin B2, respectively. Detection limits of 0.66 and $0.60 \mathrm{ppm}$ have been obtained for catechin and gallic acid, respectively, using reverse phase liquid chromatography with a mixture of acetonitrile-water-phosphoric acid as the mobile phase [35]. Quantification limits of 1.3 and $1.4 \mathrm{ppm}$ for epicatechin and procyanidin B2, respectively, have been obtained using a methanol-water-Acetic acid mixture [36]. The method was repeated for the four phenolic compounds by measuring each concentration in triplicate using the calibration curves. The coefficient of variation ranged between 0.53 and $1.45 \%$ for the four compounds, values which are below $5 \%$, as suggested by other authors for the analysis of these compounds [35]. Reproducibility was evaluated by determining the coefficient of variation for areas throughout the working range at concentrations of 10,50 , and $100 \mathrm{ppm}$, in which coefficients of variation were observed in the range of 1.21 to $1.78 \%$ for the four phenolic compounds. The coefficients of variation were lower than $5 \%$, showing good reproducibility of the method. The accuracy of the system was determined in the working curves, looking at the recovery areas in each of the working curves. Accuracy was defined as $t_{\text {obt }}$ being less than $t_{\text {table }}$. The $t_{\text {table }}$ value was determined taking into account the total number of areas; thus, $t_{\text {table }}$ for eight degrees of freedom and a $95 \%$ confidence level is 2.306. It was found that for gallic acid, catechin, epicatechin, and procyanidin $\mathrm{B} 2, \mathrm{t}_{\mathrm{obt}}$ is less than $\mathrm{t}_{\text {table }}$, with no significant differences between mean recovery time and 100 . Overall, percent recovery data correspond to the ratio of the value of the concentration giving the signal and the concentration of the standard prepared. Validation data of the chromatographic method for the determination of phenolic compounds in Pinus patula bark were within the limits established by Gutierrez et al. [37] for linearity $\left(r^{2}=0.99\right)$, repeatability $(\% \mathrm{RSD}<5 \%)$, reproducibility ( $\% \mathrm{RSD}<5 \%$ ), and accuracy with $\mathrm{t}_{\mathrm{obt}}<\mathrm{t}_{\text {table }}=2.306$ for $\mathrm{n}=9$ and $95 \%$ confidence. To eliminate interference, solid phase extraction (SPE) was used for phenolic compounds [26]. After SPE, the sample is concentrated using a nitrogen and water bath. Three milliliters of mobile phase are then added, and the chromatographic analysis is carried out. SPE accuracy was determined using the Student's $t$-test in

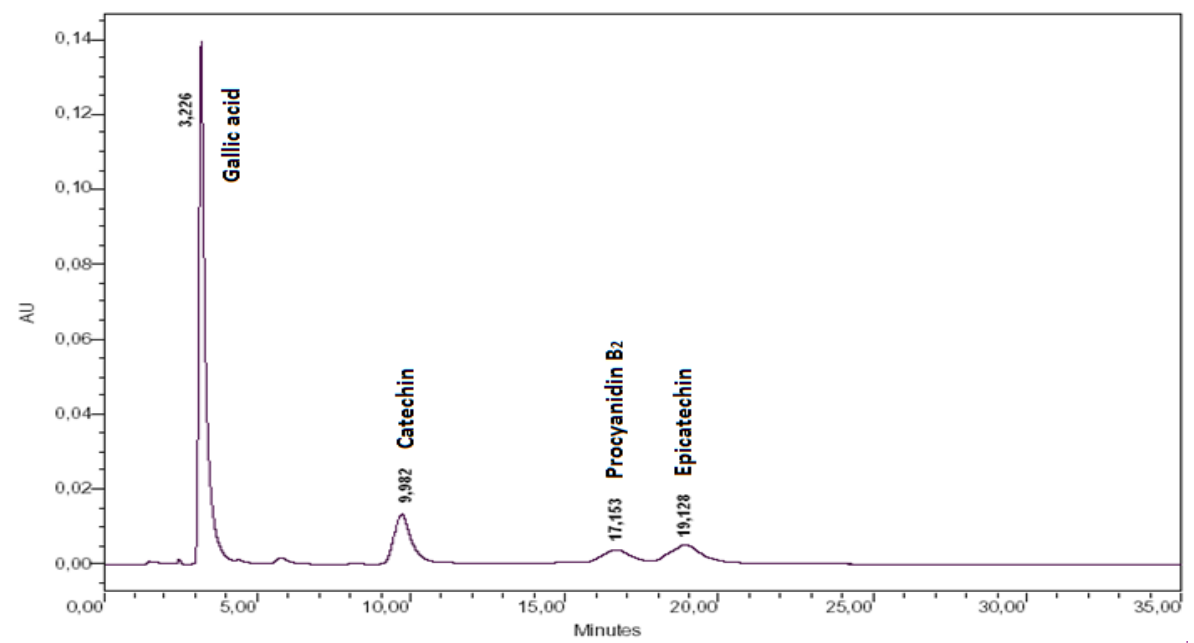

Figure 1: Chromatogram of the mixture of gallic acid, catechin, epicatechin, and procyanidin B under optimum working conditions. 
the chromatographic range and using standards of gallic acid, catechin, epicatechin, and procyanidin B2. Mixtures of these standards at 10, 50, and $100 \mathrm{ppm}$ were used, performing SPE in triplicate for each. Table 1 shows the average percent recovery and $t_{\text {obt }}$ for gallic acid, catechin, epicatechin, and procyanidin B2 to be 101.58 and $0.82,101.59$ and 1.21 , 96.21 and 2.21 , and 98.17 and 1.31 , respectively.

With SPE, percent recoveries of 97.86 and $96.40 \%$ have been obtained for Gallic acid and catechin, respectively [35]. For epicatechin and procyanidin B2, percent recoveries of 96.0 and $92.6 \%$ have been obtained, respectively, using Superspher 100 RP-18 $(4 \mu \mathrm{m})$ cartridges (Merck) [38]. The Student's t-test was applied to nine samples $(n=9)$, with a $t_{\text {table }}$ of 2.306 for eight degrees of freedom and 95\% confidence. In all four phenolic compounds, $t_{\text {obt }}<t_{\text {table }}$, showing the relationship between percent recovery at the concentration giving the signal and the extracted external standard. When performing the extraction, a blank was prepared for the cartridge and solvents used for extraction. The hydroalcoholic extract of Pinus patula bark was submitted to the SPE process, and identification and quantification of gallic acid, catechin, epicatechin, and procyanidin B2 in the sample was performed. Pinus patula bark extract was found to have contents of gallic acid, catechin, epicatechin, and procyanidin B2 of 3.12, 1.99, 0.80 and $0.71 \%$, respectively. There have been reports of catechin and epicatechin contents of 8.1 and $10.4 \%$, respectively, in Pinus pinaster bark [39]. In the bark of Pinus sylvestris from Sweden, twenty-six phenolic compounds were found, with catechins and procyanidins being the major constituents [8]. In grape seed extract, a percentage of phenolic compounds of low molecular weight has also been found, which include gallic acid, catechin, epicatechin, and procyanidin B1, B2, and C estimated at between 5.5 and $12.2 \%(\mathrm{w} / \mathrm{w})$ [40]. In extracts of pine bark (Pinus maritima L.), the following contents have been reported: $24.4 \mathrm{mg} / \mathrm{g}$ of gallic acid; $74.2 \mathrm{mg} / \mathrm{g}$ of catechin, epicatechin, and gallocatechin; and $285.3 \mathrm{mg} / \mathrm{g}$ of procyanidin and gallocatechin dimers [41]. In wine, the following contents have been reported: $320,145,128$, and $30 \mathrm{mg}$ of gallic acid, catechin, epicatechin, and procyanidin B2, respectively [42]. Total catechins, procyanidin dimers, trimers and tetramers in directly peeled peanut skin were 16.1, 111.3, 221.3 and $296.1 \mathrm{mg} / 100 \mathrm{~g}$, respectively [43]. In studies carried out by Yesil-Celiktas et al. [44], the ethyl acetate phase of the extract obtained from four types of barks from species from Turkey were analyzed by HPLC (LC-MS). The authors found that the extract from P. brutia bark contained $18.6 \%$ taxifolin and $7 \%$ catechin (percent of each compound in the respective pine bark extract). The GC-MS chromatogram of the ethyl acetate extract showed high amounts of taxifolin $(\geq 80 \%$ of the total peak area) with small amounts of taxifolin isomer (2\%). Additionally, small amounts of catechin $(2 \%)$ and quercetin $(0.4 \%)$ and other low amounts of ferulic acid $(<0.1 \%)$, glycerol $(2.5 \%)$, p-hydroxybenzoic acid (0.5\%), and 3,4-dihydroxybenzoic acid (2.5\%) were identified. According to several studies, approximately 15 to $30 \%$ of Pinus brutia bark extract is composed of monomeric flavonoids, with taxifolin being the predominant compound $[44,45]$. Figure 2 shows the chromatogram of the hydroalcoholic extract of Pinus patula bark. In Figure 2, the compounds labeled 1, 4, 6, and 7 correspond to gallic acid, catechin, procyanidin $\mathrm{B} 2$, and epicatechin, respectively. Given that the process of solid-phase extraction is specific for phenolic compounds, it could be thought that chromatogram peaks correspond to phenolic compounds. It is worth mentioning that pine bark has other phenolic compounds, such as caffeic and ferulic acids, catechin and epicatechin dimers, and other constituents including trimers and tetramers [46].

According to the chromatogram and taking into account the studies conducted by Escribano-Bailon et al. [47], compounds 2 and 3 could correspond to other Phenolic acids and peak 5 could correspond to quercetin, as it is a very common compound in the bark of pine grown in Colombia [48]. The peaks numbered 8, 9, and 10 may correspond to condensed flavonoids such as catechin (procyanidins) or hydrolysable tannins (gallotannins) [49]. The Gebert method [22], indicated for the separation of flavanols and Phenolic acids, was used to isolate catechin and gallic acid. The process started with $1000 \mathrm{~g}$ of pine bark, previously degreased with hexane, and then, the extraction of phenolic compounds was carried out under the best extraction conditions. After roto evaporating the mixture at $55^{\circ} \mathrm{C}, 75.0245 \mathrm{~g}$ of extract was obtained. An amount of $7.5102 \mathrm{~g}$ of hydroalcoholic extract was taken and divided into two fractions, one soluble in ethanol $(2.9785 \mathrm{~g})$ and the other insoluble in ethanol $(4.2931 \mathrm{~g})$. The hydroalcoholic fraction obtained was extracted with water and separated into two fractions, a soluble one $(1.5677 \mathrm{~g})$ (crude tannin, fraction $\left.\mathrm{T}_{1}\right)$ and an insoluble fraction (3.8513 g) (crude phlobaphenes, fraction $\mathrm{F}_{1}$ ). Crude phlobaphenes were washed three times with ethyl ether, and the insoluble fraction was extracted three times with ethyl acetate. The soluble fraction was discarded and not subjected to further analysis. The insoluble fraction in ethyl acetate was rot evaporated at $55^{\circ} \mathrm{C}$, yielding $3.6234 \mathrm{~g}$ of a red colored solid. The infrared spectrum of phlobaphenes showed bands at 3382, 871 and 756 $\mathrm{cm}^{-1}$ corresponding to aliphatic and aromatic $-\mathrm{OH}$ elongations. Bands for vibrations of $\mathrm{C}=\mathrm{C}$ aromatic rings were observed at 2362, 1614 and $1532 \mathrm{~cm}^{-1}$. A band for $\mathrm{C}=\mathrm{O}$ elongations non-conjugated to an aromatic

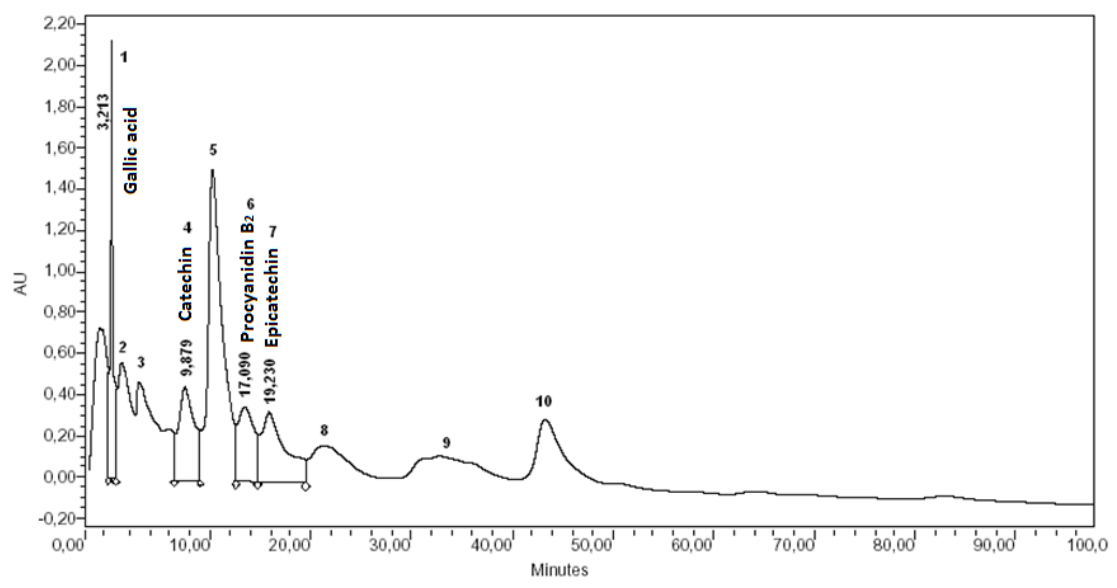

Figure 2: Chromatogram of the hydro alcoholic extract of Pinus patula bark. 
ring was observed at $1713 \mathrm{~cm}^{-1}$. A siringil ring vibration is observed at $1327 \mathrm{~cm}^{-1}$. Characteristic bands for C-O bonds and vibration appeared at 1204 and $586 \mathrm{~cm}^{-1}$, respectively; and bands for $\mathrm{C}-\mathrm{H}$ deformations were shown at 1449, 1087 and $1029 \mathrm{~cm}^{-1}$ [50]. Crude tannins were washed successively with ethyl ether, a number of times sufficient to obtain spots only near the origin of the chromatogram using twodimensional paper chromatography, excluding the presence of other compounds such as Phenolic acids. To this end, paper chromatography (Whatman 3) was used $(37 \mathrm{~cm} \times 47 \mathrm{~cm})$ with n-butanol-Acetic acidwater (3:1:1) as the eluent in the first direction and $15 \%(\mathrm{w} / \mathrm{v})$ aqueous Acetic acid in the second direction. The developers used were iron chloride, ultraviolet light, and iodine vapor. Subsequently, this fraction was injected into the liquid chromatograph to ensure the presence of catechin $\mathrm{Cf}_{1}$. Figure 3 shows the chromatogram of the crude tannin fraction. The chromatogram in Figure 3 shows the presence of catechin at a retention time of 9.910 minutes. Other compounds are also present in the chromatogram: the peaks at 17.110 minutes (9) and 19.210 minutes (10) may correspond to procyanidin B2 and epicatechin, respectively. Peaks $1,3,4,5,6,7$, and 8 correspond to other possible monomeric phenolic compounds present in this fraction.

Phenolic compounds such as catechin, epicatechin, and procyanidin B2 and B3 have been determined in crude tannins of grape seed [51]. Crude tannins $\left(\mathrm{T}_{1}\right)$ were washed with ether and ethyl acetate (fraction $\left.\mathrm{T}_{2}\right)$ and passed through a Sephadex G-25 column $(30 \mathrm{~cm} \times 2 \mathrm{~cm})$, eluting with methanol followed by a methanol-ethyl acetate mixture $1: 1(\mathrm{v} / \mathrm{v})$. Sixteen fractions were obtained, which underwent TLC with tolueneacetone-formic acid (3:6:1). The plates were then developed with ferric chloride, a UV lamp, vanillin, and iodine vapor. Fractions 9-16 were discarded, as no phenolic compounds were present. Fractions 1-8 underwent a second round of TLC, and developers indicated the same compound, presenting an Rf of 0.86 , with some type of interference from other compounds ( $\mathrm{Rf} 0.8$ and 0.74 ). The eight fractions were pooled, and roto evaporated to concentrate the solution, which was again separated on a silica column $(20 \mathrm{~cm} \times 2 \mathrm{~cm})$. The fractions were eluted with a mixture of chloroform-methanol, gradually increasing the proportion of methanol to $100 \%$. A total of 18 fractions were obtained, out of which the top 10 had the same compound at $\mathrm{Rf}(0.86)$. These fractions were pooled, roto evaporated, and finally purified on a $\mathrm{C}_{18}$ column $(20 \mathrm{~cm} \times 2 \mathrm{~cm})$ using acetonitrile-ethyl acetate 3:1 (v/v). After rot evaporation, a light-yellow precipitate was obtained $(200 \mathrm{mg}) \mathrm{Cf}_{1}$. Methanol recrystallization was performed to obtain a final precipitate of $96 \mathrm{mg}$ [3]. The ethanol-insoluble fraction was extracted with a $1 \%(\mathrm{w} / \mathrm{v})$
$\mathrm{NaOH}$ aqueous solution and heated at $80^{\circ} \mathrm{C}$ for 4 hours. The soluble fraction mainly corresponds to an aqueous solution of the sodium salt of Phenolic acids, which subsequently were separated by precipitation with a concentrated $\mathrm{HCl}$ solution (fraction $\mathrm{AF}_{1}$ ). The phenolic acid fraction was injected into the liquid chromatograph to determine the presence of Gallic acid $\mathrm{Cf}_{2}$. Figure 4 shows the chromatogram of the phenolic acid fraction. The chromatogram in Figure 4 shows the presence of Gallic acid at 3.210 minutes.

Gallic acid $\left(\mathrm{Cf}_{2}\right)$ showed an intense band in the UV-visible spectrum in methanol at $212.4 \mathrm{~nm}$ and a medium intensity band at $260.6 \mathrm{~nm}$, characteristic of flavonoids. The infrared spectrum of Gallic acid $\left(\mathrm{Cf}_{2}\right.$ ) showed a stretching vibration of $-\mathrm{OH}$ at $3464.88 \mathrm{~cm}^{-1}$ and a band at $1705.92 \mathrm{~cm}^{-1}$ corresponding to a $\mathrm{C}=\mathrm{O}$ bond tension. There was a C-O stretching band at $1246.90 \mathrm{~cm}^{-1}$. Two $\mathrm{O}-\mathrm{H}$ bending bands can be observed at $1448.44 \mathrm{~cm}^{-1}$ and $868.87 \mathrm{~cm}^{-1}$. A C $=\mathrm{C}$ stretching vibration can be observed at $1526.55 \mathrm{~cm}^{-1}$. A band can be observed at $821.62 \mathrm{~cm}^{-1}$ corresponding to a vibration of the $\mathrm{O}-\mathrm{H}$ deformation. Mass spectrum (EIMS $70 \mathrm{eV}$ ) analysis of $\mathrm{Cf}_{2}$ presents the molecular ion at $\mathrm{m} / \mathrm{z} 170$, coincident with the molecular formula of a phenolic acid such as Gallic acid $\left(\mathrm{C}_{7} \mathrm{H}_{6} \mathrm{O}_{5}\right)$, with a relative intensity of $100 \%$, which also corresponds to the base peak, characteristic of phenols whose molecular ion peak is also its base [52-62]. The presence of the main ions at $\mathrm{m} / \mathrm{z}$ values of 153 , 135,125 , and 107 are due to loss of acid and hydroxyl functional groups. Ions at $\mathrm{m} / \mathrm{z}$ values of $96,79,68,51$, and 39 correspond to characteristic aromatic ring breakdowns. Tables 2 and 3 shows the $\mathrm{Cf}_{2}$ mass spectrum data. Figures 5-7 shows the mass spectrum of Gallic acid.

\section{Conclusions}

The extraction of phenolic compounds from $P$. patula bark was successfully performed. The ethanolic extract was divided into different fractions to isolate Gallic acid and catechin. The content of phenolic compounds in the Pinus patula bark extract was determined by HPLC with $3.120 \%$ of gallic acid, $1.990 \%$ of catechin, $0.801 \%$ of epicatechin, and $0.706 \%$ of procyanidin B2. Solid-phase extraction and HPLC made it possible to properly clean and isolate the phenolic compounds present in the Pinus patula bark. The phytochemical study of Pinus patula bark resulted in the identification of two phenolic compounds (Gallic acid and catechin). These compounds were isolated using different laboratory techniques, including percolation, TLC, CC (Sephadex, silica and $\mathrm{C}_{18}$ ), and recrystallization for purification. Structural elucidation was performed using UV-V is, IR, ${ }^{1} \mathrm{H}$ and ${ }^{13} \mathrm{C}$ NMR spectroscopic techniques to ascertain the chemical structure of

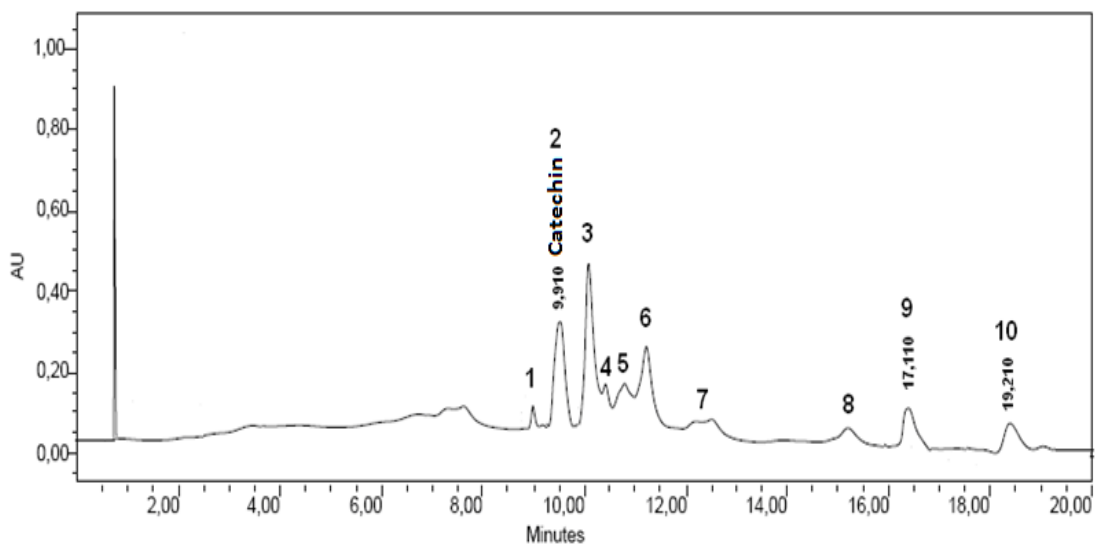

Figure 3: Chromatogram of crude tannins. 
Citation: Sarria-Villa RA, Gallo-Corredor JA, Páez MI (2017) Isolation of Catechin and Gallic Acid from Colombian Bark of Pinus patula. Chem Sci J 8: 174. doi: 10.4172/2150-3494.1000174

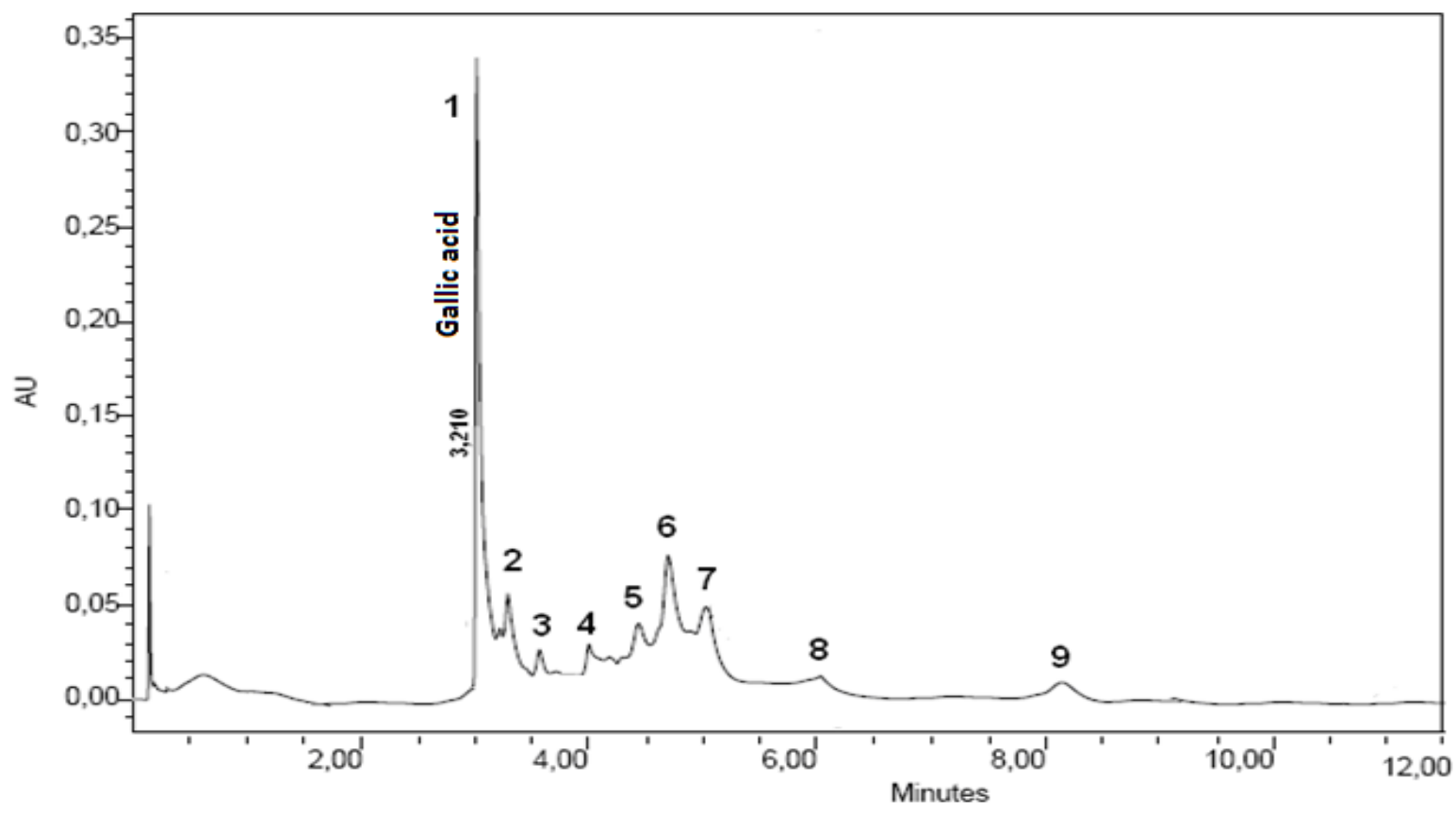

Figure 4: Chromatogram of the phenolic acid fraction.

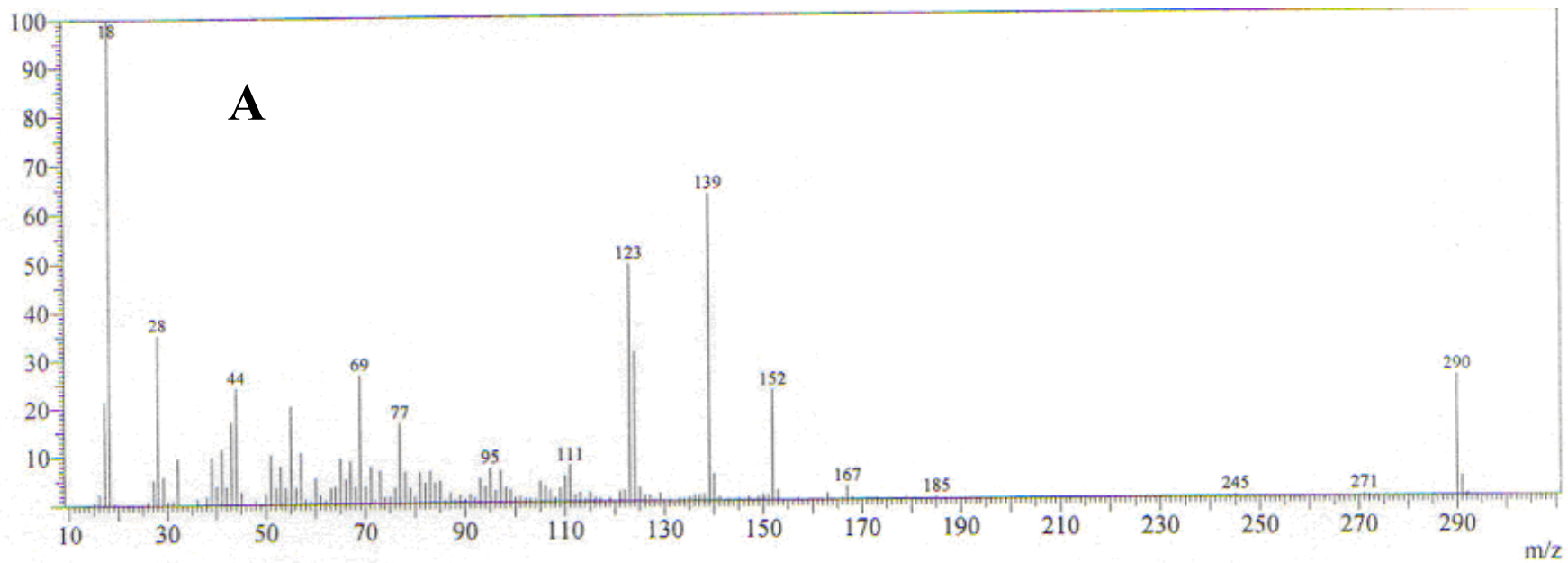

Figure 5: Mass spectra of $(A)$ Catechin $\left(C f_{1}\right)$ and $(B)$ Gallic acid $\left(C f_{2}\right)$.

\begin{tabular}{|c|c|c|c|}
\hline Phenolic compound & Percent of average recovery & Standard deviation & Coefficient of variation \\
\hline Gallic acid & 101.58 & 2.11 & 2.1 \\
\hline Catechin & 101.59 & 4.01 & 0.82 \\
\hline Epicatechin & 96.21 & 4.96 & 5.95 \\
\hline Procyanidin B2 & 98.17 & 4.13 & 2.15 \\
\hline
\end{tabular}

$\mathrm{T}_{\text {table }}=2.306$ for $\mathrm{n}=9$ and $95 \%$ confidence

Table 1: SPE accuracy data for the extraction of phenolic compounds. 
Citation: Sarria-Villa RA, Gallo-Corredor JA, Páez MI (2017) Isolation of Catechin and Gallic Acid from Colombian Bark of Pinus patula. Chem Sci J 8: 174. doi: 10.4172/2150-3494.1000174

Page 7 of 11

\begin{tabular}{|c|c|c|c|}
\hline \multicolumn{2}{|c|}{ Phenolic compound $\mathrm{Cf}_{1}{ }^{*}$} & \multicolumn{2}{|c|}{ Phenolic compound $\mathrm{Cf}_{2}{ }^{*}$} \\
\hline Experimental, $\mathrm{m} / \mathrm{z}$ & Reported, $\mathrm{m} / \mathbf{z}$ & Experimental, $\mathbf{m} / \mathbf{z}$ & Reported, m/z \\
\hline $290.00(25.25)\left(\mathrm{M}^{+}\right)$ & $291.00(4.1)$ & $169.95(100.00)\left(\mathrm{M}^{+}\right.$, B.P. $)$ & 170.00 (100.00) (B.P.) \\
\hline $152.00(22.98)$ & $152.00(47.1)$ & $154.00(6.77)$ & $154.00(5.5)$ \\
\hline $139.05(63.34)$ & 139.00 (100) (B.P.) & $153.00(85.84)$ & $153.00(69.00)$ \\
\hline $124.05(31.12)$ & $124.0(20.6)$ & $135.00(8.32)$ & $135.00(7.30)$ \\
\hline $123.05(49.19)$ & $123.0(51.8)$ & $125.95(4.41)$ & $126.00(15.80)$ \\
\hline $111.05(7.67)$ & $111.0(2.3)$ & $125.00(51.18)$ & $125.00(15.00)$ \\
\hline $95.05(7.23)$ & $95.0(2.6)$ & $113.00(17.85)$ & $113.00(4.50)$ \\
\hline $77.05(16.65)$ & $77.0(9.7)$ & $107.00(20.73)$ & $107.00(5.30)$ \\
\hline $69.00(26.67)$ & $69.0(9.5)$ & $96.00(20.65)$ & $96.00(3.80)$ \\
\hline $55.05(20.29)$ & $55.0(7.9)$ & $79.00(81.12)$ & $79.00(14.50)$ \\
\hline $44.05(24.13)$ & $44.0(2.3)$ & $71.00(27.15)$ & $71.00(3.50)$ \\
\hline $28.10(35.26)$ & $28.0(7.3)$ & $69.00(20.32)$ & $69.00(2.60)$ \\
\hline 18.20 (100) (B.P.) & $18.0(28.7)$ & $68.00(29.45)$ & $68.00(4.80)$ \\
\hline $17.20(21.45)$ & $17.0(4.7)$ & $53.05(53.30)$ & $53.00(8.70)$ \\
\hline- & - & $51.05(74.90)$ & $51.00(12.90)$ \\
\hline- & - & $50.05(42.93)$ & $50.00(6.70)$ \\
\hline- & - & $39.10(75.24)$ & $39.00(11.00)$ \\
\hline- & - & $38.10(31.94)$ & $38.00(4.80)$ \\
\hline- & - & $29.10(23.65)$ & $29.00(3.90)$ \\
\hline- & - & $18.20(29.98)$ & $18.00(3.20)$ \\
\hline
\end{tabular}

B.P.=Base Peak, $\mathrm{M}^{+}=$Molecular lon, *=Relative Intensity

Table 2: Electron Impact Mass Spectrum (EIMS) of $\mathrm{Cf}_{1}$ and $\mathrm{Cf}_{2}$

\begin{tabular}{|c|c|c|c|c|c|c|c|c|c|}
\hline${ }^{1} \mathrm{H}$ NMR (ppm) & ${ }^{1} \mathrm{H}$ NMR (ppm)* & ${ }^{13} \mathrm{C}$ NMR (ppm) & ${ }^{13} \mathrm{C}$ NMR (ppm)* & \multirow{3}{*}{$\#$} & \multirow{3}{*}{${ }^{\mathrm{a}} \mathrm{C}$} & \multirow{3}{*}{$\delta_{\mathrm{H}}^{\mathrm{a}}(\mathrm{J}$ in Hz) } & \multirow{3}{*}{ Integral } & \multirow{3}{*}{ HSQC } & \multirow{3}{*}{ HMBC } \\
\hline Experimental & Reported & Experimental & Reported & & & & & & \\
\hline acetone-d6 & acetone-d6 & acetone-d6 & acetone-d6 & & & & & & \\
\hline \multicolumn{10}{|l|}{ Catechin Cf1 } \\
\hline $2.55\left(\mathrm{dd}, 1 \mathrm{H}, \mathrm{H}-4^{\mathrm{a}}\right)$ & $2.56(\mathrm{dd}, 1 \mathrm{H}, \mathrm{H}-4 \mathrm{~A})$ & $27.96(\mathrm{C}-4)$ & $28.66(C-4)$ & 2 & 81.78 & $4.58, \mathrm{~d}$ & 1 & $\mathrm{H}-2$ & $\mathrm{H} 4 \mathrm{~B}, \mathrm{H}-8$ \\
\hline $2.91(\mathrm{dd}, 1 \mathrm{H}, \mathrm{H}-4 \mathrm{~B})$ & $2.93(\mathrm{dd}, 1 \mathrm{H}, \mathrm{H}-4 \mathrm{~B})$ & $67.44(\mathrm{C}-3)$ & $68.33(\mathrm{C}-3)$ & 3 & 67.44 & 4.010, m & 1 & $\mathrm{H}-3$ & $\mathrm{H} 4 \mathrm{~A}, \mathrm{H} 4 \mathrm{~B}, \mathrm{H} 2$ \\
\hline $3.20(\mathrm{~s}, \mathrm{OH}-3)$ & $3.46(\mathrm{~s}, \mathrm{OH}-3)$ & $81.78(\mathrm{C}-2)$ & $82.56(\mathrm{C}-2)$ & 4 & 27.96 & $2.55, \mathrm{dd} ; 2.91, \mathrm{dd}$ & $1 ; 1$ & $\mathrm{H}-4^{\mathrm{a}}, \mathrm{H}-4 \mathrm{~B}$ & \\
\hline $4.010(\mathrm{~m}, 1 \mathrm{H}, \mathrm{H}-3)$ & $4.04(\mathrm{~m}, 1 \mathrm{H}, \mathrm{H}-3)$ & $94.48(\mathrm{C}-8)$ & $95.45(C-8)$ & 5 & 156.36 & & & & \\
\hline $4.58(\mathrm{~d}, 1 \mathrm{H}, \mathrm{H}-2)$ & $4.59(\mathrm{~d}, 1 \mathrm{H}, \mathrm{H}-2)$ & $95.30(\mathrm{C}-6)$ & $96.17(\mathrm{C}-6)$ & 6 & 95.3 & $6.03, \mathrm{~d}, 2.3$ & 1 & $\mathrm{H}-6$ & \\
\hline $5.89(\mathrm{~d}, 1 \mathrm{H}, \mathrm{H}-8)$ & $5.90(\mathrm{~d}, 1 \mathrm{H}, \mathrm{H}-6)$ & $99.69\left(\mathrm{C}-10\left[4^{\mathrm{a}}\right]\right)$ & $100.60\left(\mathrm{C}-10\left[4^{\mathrm{a}}\right]\right)$ & 7 & 156.86 & & & & \\
\hline $6.03(\mathrm{~d}, 1 \mathrm{H}, \mathrm{H}-6)$ & $6.04(\mathrm{~d}, 1 \mathrm{H}, \mathrm{H}-8)$ & $114.37\left(\mathrm{C}-2^{\prime}\right)$ & $115.20\left(\mathrm{C}-2^{\prime}\right)$ & 8 & 94.48 & $5.89, \mathrm{~d}, 2.3$ & 1 & $\mathrm{H}-8$ & $\mathrm{H}-6$ \\
\hline $6.75\left(\mathrm{dd}, 1 \mathrm{H}, \mathrm{H}-6^{\prime}\right)$ & $6.77\left(\mathrm{dd}, 1 \mathrm{H}, \mathrm{H}-6^{\prime}\right)$ & $114.80(C-5 ’)$ & $115.33\left(\mathrm{C}-5^{\prime}\right)$ & 9 & 155.95 & & & & \\
\hline $6.79\left(\mathrm{~d}, 1 \mathrm{H}, \mathrm{H}-5^{\prime}\right)$ & $6.81\left(\mathrm{~d}, 1 \mathrm{H}, \mathrm{H}-5^{\prime}\right)$ & $119.12\left(\mathrm{C}-6^{\prime}\right)$ & $120.04\left(\mathrm{C}-6^{\prime}\right)$ & 10 & 99.69 & & & & $\mathrm{H} 4 \mathrm{~A}, \mathrm{H} 4 \mathrm{~B}, \mathrm{H} 6$ \\
\hline $6.90\left(\mathrm{~d}, 1 \mathrm{H}, \mathrm{H}-2^{\prime}\right)$ & $6.91\left(\mathrm{~d}, 1 \mathrm{H}, \mathrm{H}-2^{\prime}\right)$ & $131.16\left(\mathrm{C}-1^{\prime}\right)$ & $132.09\left(\mathrm{C}-1^{\prime}\right)$ & 1 ' & 131.16 & & & & $\mathrm{H} 6^{\prime}$ \\
\hline 7.94 (d, OH's, 3', 4') & $8.01(4 \mathrm{OH})$ & $144.81\left(\mathrm{C}-3^{\prime}\right)$ & $145.58\left(\mathrm{C}-3^{\prime}\right)$ & $2^{\prime}$ & 114.37 & $6.90, \mathrm{~d}, 2.00$ & 1 & $\mathrm{H}-2^{\prime}$ & H6', H2 \\
\hline $8.29(\mathrm{~d}, \mathrm{OH} \mathrm{s}, 5,7)$ & & $144.87\left(\mathrm{C}-4^{\prime}\right)$ & $145.64\left(C-4^{\prime}\right)$ & $3^{\prime}$ & 144.81 & & & & \\
\hline- & - & $155.95\left(C-9\left[4^{a}\right]\right)$ & $156.82\left(\mathrm{C}-9\left[^{\mathrm{a}}\right]\right)$ & $4^{\prime}$ & 144.87 & & & & H6', $6^{\prime}{ }^{\prime}{ }^{\prime} 2^{\prime}$ \\
\hline- & - & $156.36(\mathrm{C}-5)$ & $157.14(\mathrm{C}-5)$ & 5 & 114.8 & $6.79, \mathrm{~d}, 8.55$ & 1 & $\mathrm{H}-5$ & \\
\hline- & - & $156.86(\mathrm{C}-7)$ & $157.63(\mathrm{C}-7)$ & $6^{\prime}$ & 119.12 & $\begin{array}{c}6.75, \mathrm{dd}, 8.55 \\
2.00\end{array}$ & 1 & $\mathrm{H}-6$ & $\mathrm{H}-2^{\prime}$ \\
\hline- & - & - & - & - & - & - & - & - & - \\
\hline \multicolumn{10}{|l|}{ Gallic acid Cf2 } \\
\hline \multirow[t]{3}{*}{$7.16(\mathrm{~s}, \mathrm{H}-2, \mathrm{H}-6)$} & $7.10(\mathrm{~s}, \mathrm{H}-2, \mathrm{H}-6)$ & $109.22(C-2, C-6)$ & $110.52(\mathrm{C}-2, \mathrm{C}-6)$ & 1 & 121.09 & & & & $\mathrm{H} 2, \mathrm{H} 6$ \\
\hline & & $121.09(\mathrm{C}-1)$ & $121.38(\mathrm{C}-1)$ & 2 & 109.22 & $7.16, \mathrm{~s}$ & 1 & $\mathrm{H}-2$ & $\mathrm{H} 6$ \\
\hline & & $137.81(\mathrm{C}-4)$ & $135.93(\mathrm{C}-4)$ & 3 & 145.1 & & & & $\mathrm{H} 2$ \\
\hline
\end{tabular}


Citation: Sarria-Villa RA, Gallo-Corredor JA, Páez MI (2017) Isolation of Catechin and Gallic Acid from Colombian Bark of Pinus patula. Chem Sci J 8: 174. doi: 10.4172/2150-3494.1000174

Page 8 of 11

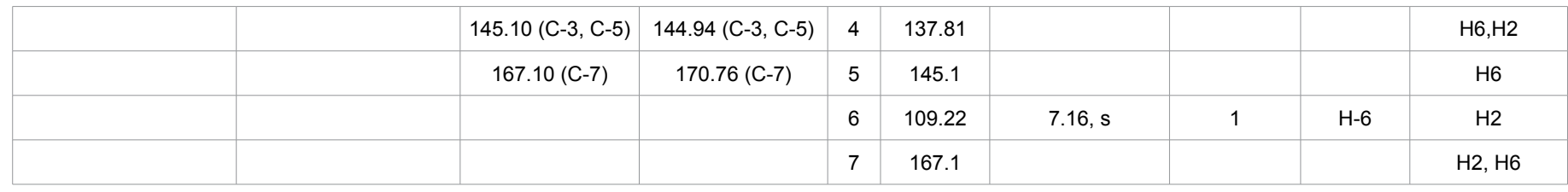

${ }^{\mathrm{a}}=$ displacement in $\mathrm{ppm}$

Table 3: NMR, ${ }^{13} \mathrm{C}$ NMR, ${ }^{1} \mathrm{H}, \mathrm{HSQC}$, and $\mathrm{HMBC}$ spectroscopy data of $\mathrm{Cf}_{1}$ and $\mathrm{Cf}_{2}$.

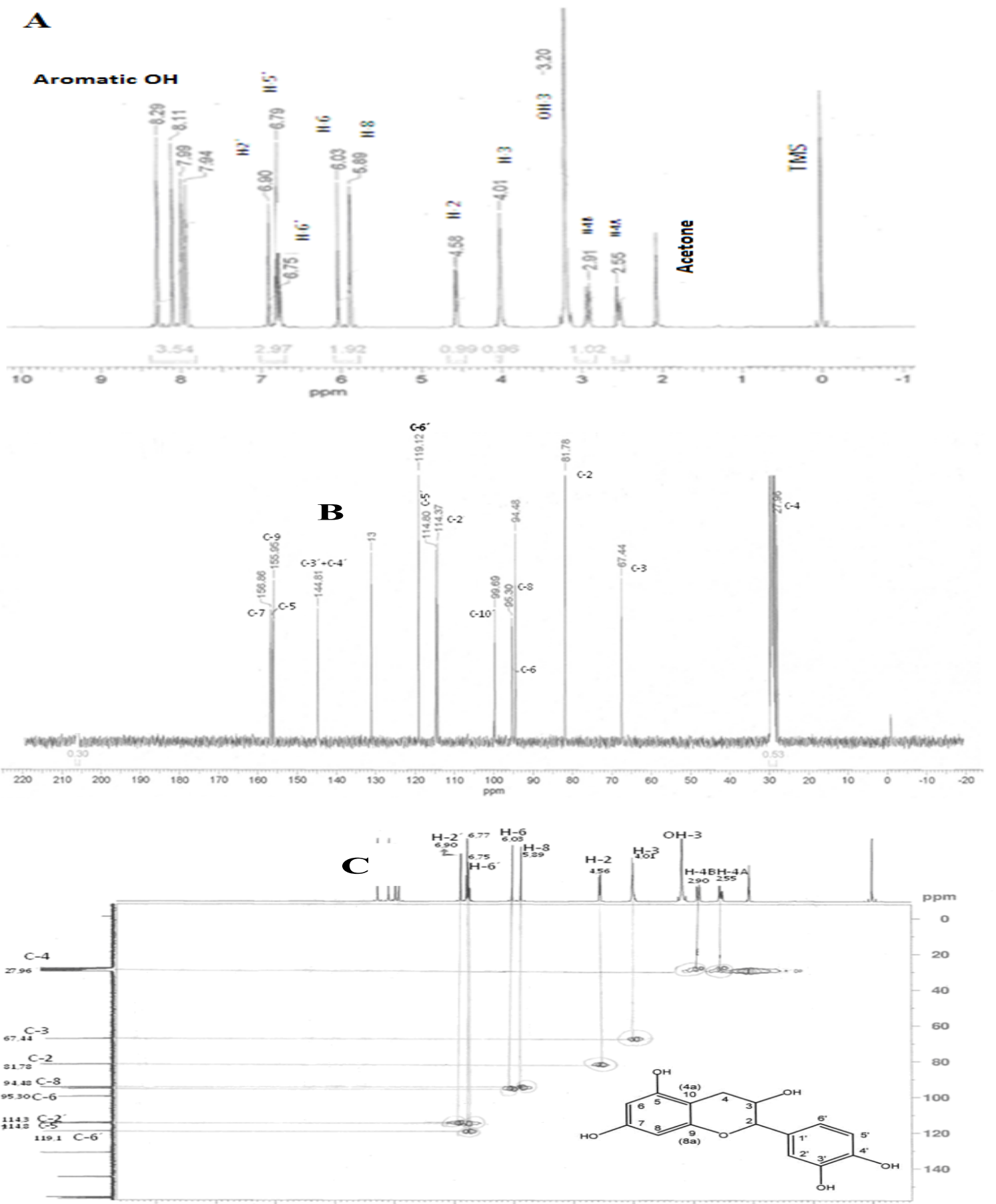

Figure 6: NMR spectra: (A) H, (B) C13, and (C) HSQC of catechin $\left(\mathrm{Cf}_{1}\right)$. 

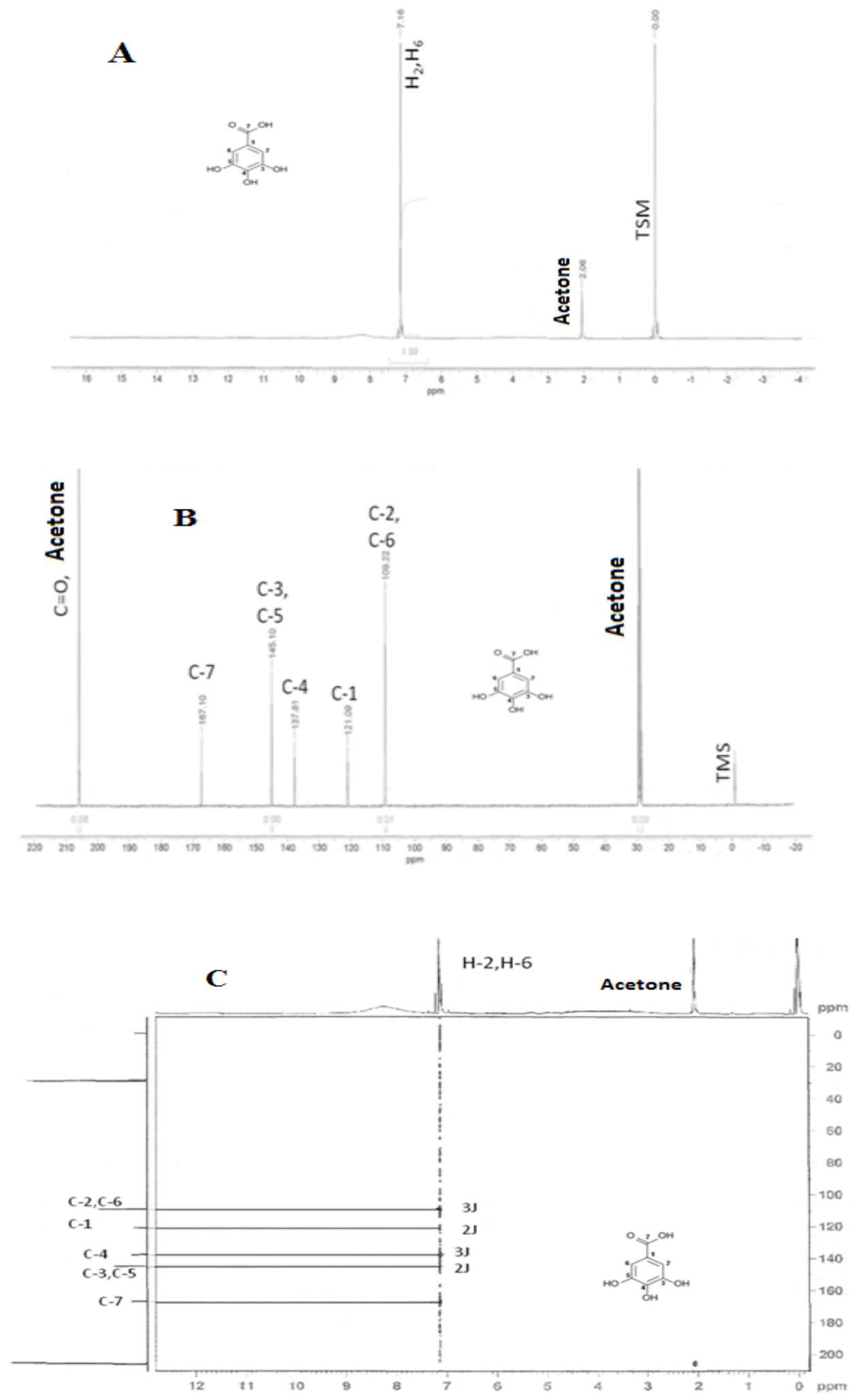

Figure 7: NMR spectra: (A) $\mathrm{H},(B) \mathrm{C} 13$ and $(\mathrm{C}) \mathrm{HMBC}$ of gallic acid $\left(\mathrm{Cf}_{2}\right)$. 
Citation: Sarria-Villa RA, Gallo-Corredor JA, Páez MI (2017) Isolation of Catechin and Gallic Acid from Colombian Bark of Pinus patula. Chem Sci J 8: 174. doi: 10.4172/2150-3494.1000174

catechin and Gallic acid isolated from Pinus patula bark.

\section{Acknowledgements}

The authors wish to thank the research groups of GICAMP from the Department of Chemistry at the University of Valle and GIQA from the Department of Chemistry at the University of Cauca for their support during the course of this investigation.

\section{References}

1. Navarrete P, Pizzi A, Pasch H, Rode K, Delmotte L (2010) MALDI-TOF and 13C NMR characterization of maritime pine industrial tannin extract. Ind Crops Prod 32: 105-110.

2. Chupin L, Motillon C, Charrier-El Bouhtoury F, Pizzi A, Charrier B (2013) Characterization of maritime pine (Pinus pinaster) bark tannins extracted under different conditions by spectroscopic methods, FTIR and HPLC. Industrial Crops and Products 49: 897-903.

3. Sjöström E (1981) Wood Chemistry Fundamentals and Applications Academic Press New york, pp. 223

4. Inoue S, Asaga M, Ogi T, Yazaki Y (1998) Extraction of polyflavonoids from radiata pine bark using hot compressed water at temperatures higher than $100^{\circ} \mathrm{C}$. Holzforschung 52: 139-145.

5. Vázquez G, Antorrena G, Parajó C (1987) Studies on the utilization of Pinus pinaster bark. Wood Science and Technology 21: 65-74.

6. Laks EP, Mckaig AP (1988) Flavonoid biocides: Word preservatives based on condensed tannins. Holzforschung 42: 299-306.

7. Rosales C, Galindo C, Gonzáles L (2002) Comparison of the content of compounds phenolic in the bark of eight species of pine Chile 13: 39-42.

8. Pan H (1995) Studies on phenolic and terpenoid constituents extracted from bark of birch, spruce and pine in Sweden Doctoral Thesis Dissertation, Sweden.

9. Li YY, Feng J, Zhang XL, Meng-Qi Li, M-Q, Cui YY (2016) Effects of Pinus massoniana bark extract on the invasion capability of HeLa cells. Journal of Functional Foods 24: 520-526.

10. Soleas GJ, Diamaudis EP, Goldberg DM (1997) Resveratrol: a molecule whose time has come and gone? J Clin Lab Anal 11: 287-313.

11. Ku CS, Mun SP (2007) Characterization of proanthocyanidin in hot water extract isolated from Pinus radiata bark. Wood Sci Technol 41: 235-247.

12. Jerez M, Sineiro J, Guitian E, Nunez MJ (2009) Identification of polymeric procyanidins from pine bark by mass spectrometry. Rapid Commun Mass Spectrom 23: 4013-4018.

13. Weber HA, Hodges AE, Guthrie JR, O'Brien BO, Robaugh D, et al. (2007) Comparison of proanthocyanidins in comercial antioxidants: grape seed and pine bark extracts. J Agric Food Chem 55: 148-156.

14. Hoong YB, Pizzi A, Tahir PM, Pasch H (2010) Characterization of Acacia mangium polyflavonoid tannins by MALDI-TOF mass spectrometry and $\mathrm{CP}$ MAS 13C NMR. Eur Polym J 46: 1268-1277

15. Wei SD, Zhou HC, Lin YM (2011) Antioxidant activities of fractions of polymeric procyanidins from stem bark of Acacia confuse. Int J Mol Sci 12: 1146-1160.

16. Ucar MB, Ucar G, Pizzi A, Gonultasa O (2013) Characterization of Pinus brutia bark tannin by MALDI-TOF MS and 13C NMR. Industrial Crops and Products 49: 697-704

17. Sattler Y, Grone C, Zurk A (1993) New compounds of the manumycin group of antibiotics and a fracilitated rouce for their structure elucidation. Org Chem 58: 6583.

18. Hollman PC, Hertog MG, Katan MB (1996) Analysis and health effects of flavonoids. Food Chem 57: 43-46.

19. Cooper KA, Chopra M, Thurnham DI (2004) Wine polyphenols and promotion of cardiac health. Nutrition Research Rewiews 17: 111-129.

20. Jeszka-Skowron M, Krawczyc M, Zgola-Grześkowiak A (2015) Determination of antioxidant activity, rutin, quercetin, phenolic acids and trace elements in tea infusions: Influence of citric acid addition on extraction of metals. Journal of food composition and Analysis 40: 70-77.

21. Singleton VL, Esau $P$ (1969) Phenolic substances in grape and wine, and wine and their significance. New York: Academia Press.
22. Gebert A (1984) Study of extracts of Pinus Insigne bark for the preparation of cold-setting adhesives Degree work Conception.

23. Sun B, Spranger I, Leandro C, Ricardo da Silva J (1998) Critical factors of vanillin assay for catechins and proanthocyanidins. J Agric Food Chem 46: 4267-4274.

24. Romani A, Leri F, Turchetti B, Mulinacci N, Vincieri FF, et al. (2006) Análisis of condensed and hydrolysable tannins from commercial plant extracts. Journal of Pharmaceutical and Biomedical Analysis 41: 415-420.

25. Sarria-Villa R (2008) Sarria-Villa R (2008) Extraction and determination of phenolic compounds (Catechin, Gallic Acid) present in the bark of Pinus patulay evaluation of the anti-inflammatory activity of its hydroalcoholic extract Work of master's degree in Chemistry Universidad del Valle Cali Colombia.

26. Robards K, Antolovich M (1997) Analytical chemistry of fruit bioflavonoids: a review Anal 122: 11-34.

27. Satake T, Kamiya K, Watanabe C, Endang H, Umar M (2001) Studies on the Constituents of Bark of Parameria laevigata. Chem Pharm Bull 49: 551-557.

28. Martínez F (1983) Ministry of Agriculture, Cuba Information and Communication Agency for Agriculture (AGRINFOR) 3: 51.

29. Valls J, Figueras M, Roquet M, Arola LI (2000) Importancia de los compuestos fenólicos en la calidad de los vinos tintos de crianza Alimentación, equipos y tecnología Tarragona.

30. Castro M, Gonzáles R (2003) Comparación del contenido de compuestos fenólicos en la corteza de ocho especies de pino Madera y Bosques 9: 41-49.

31. Revilla E, Alonso E, Bourzeix M, Heredia N (1989) Flavors and off-flavors, Proceedings of the 6th International Flavor Conference, Rethymnon, Creta Grecia.

32. Gallo-Corredor J, Sarria-Villa R (2009) Conditions of extraction of tannins from the bark of Pinus patula and standardization of the chromatographic method (CLAR) for the determination of catechin. Journal of Science and Engineering 1. $7-9$

33. Treutter D, Feucht W, Santos-Buelga C (1994) Determination of catechins and procyanidins in plant extracts - a comparison of methods. Acta Hort (ISHS) 381: 789-796.

34. Rohr GE (1999) Analytical investigation and isolation of procyanidins from Crataegus leaves and flowers. $\mathrm{PhD}$ Thesis, Swiss Federal Institute of Technology, Zurich, pp. 1-10

35. Govindarajan R, Singh DP, Rawat AKS (2007) High performance liquid chromatography method for quantification of phenolics in Chyavanprash, a potent Ayurvedic drug. Journal of Pharmaceutical and Biomedical Analysis 43 : 527-532.

36. Teissedre PL, Carando S, Pascual-Martinez L, Cabanis JC (1999) Levels of flavan-3-ols in french wines. J Agric Food Chem 4: 4161-4166.

37. Gutiérrez GYI, Miranda MM, Varona TN, Rodríguez AT (2000) Validation of 2 spectrophotometric methods for the quantification of tannins and flavonoids (quercetin) in Psidium guajaba. 34: 50-5.

38. Sun B, Leandro C, Ricardo da Silva JM (1998) Separation of grape and wine proanthocyanidins according to their degree of polymerization $\mathrm{J}$ Agric Food Chem 46: 1390-1396.

39. Jerez M, Touriño S, Sineiro J, Tores J, Núñez M (2007) Procyanidins from pine bark: Relationships between structure, composition and antiradical activity. Food Chemistry 104: 518-527.

40. Nakamura Y, Tsuji S, Tonogai Y (2003) Analysis of proanthocyanidins in grape seed extracts, health foods and grape seed oils. J Health Sci 49: 45-54.

41. Romani A, Menichetti S, Arapitsas P, Nativi C, Turchetti B, et al. (2005) O-Methylglucogalloyl esters: Synthesis and evaluation of their antimycotic activity. Bioorg Med Chem Lett 15: 4000-4003.

42. Ghiselli A, Nardini M, Baldi A, Scaccini C (1998) Antioxidant Activity of Differen Phenolic Fractions Separated From an Italian Red Wine. J Agric Food Chem 46: 361-367.

43. Yu J, Ahmedna M, Goktepe I, Dai J (2006) Peanut skin procyanidins: Composition and antioxidant activities as affected by processing. Journal of food composition and Analysis 19: 364-371.

44. Yesil-Celiktas O, Ganzera M, Akgun I, Sevimli C, Korkmaz K, Bedir E (2009) 
Citation: Sarria-Villa RA, Gallo-Corredor JA, Páez MI (2017) Isolation of Catechin and Gallic Acid from Colombian Bark of Pinus patula. Chem Sci J 8: 174. doi: 10.4172/2150-3494.1000174

Determination of polyphenolic constituents and biological activities of bark extracts from different Pinus species. J Sci Food Agric 89: 1339-1345.

45. Ayla C (1980) Production of moisture-resistant glues from renewable raw materials for the wood industry-illustrated by the example of the bark extract of Pinus brutia Tenore and the Athanollignin Hamburg University (PhD thesis).

46. Rimbach G, Virgili F, Park YC, Packer L (1999) Effect of procyanidins from Pinus maritima on glutathione levels in endothelial cells challenged by 3-morpholinosydnonimine or activate macrophages. Redox Rep 4: 171-177.

47. Escribano-Bailón MT, Guitiérrez-Fernandez Y, Rivas-Gonzalo JC, SantosBuelga C (1992) Characterization of Procyanidins of Vitis vinifera Variety Tinta del Pais Grape Seeds. J Agric Food Chem 40: 1794-1799.

48. Bedrin AK (1987) White spruce bark-valuable material for the production of chemical-forest products. Guid and Lesokh Prom 5: 8-10.

49. Guyot S, Marnet N, Laraba D, Sanoner P, Drilleau JF (1998) Reversed-Phase HPLC following Thiolysis for Quantitative Estimation and Characterization of the Four Main Classes of Phenolic Compounds in Different Tissue Zones of a French Cider Apple Variety (Malus domestica Var Kermerrien). J Agric Food Chem 46: 1698-1705.

50. Marcucci M, Salatino A (2003) Use of aluminum chloride in the quantification of flavonoids in propolis samples in Bandeirante University of São Paulo, pp. 1-4

51. Jaworski, Lee (1987) Fractionation and HPLC Determination of Grape Phenolics. J Agric Food Chem 35: 257-259.

52. Touriño S, Selga A, Jimenez AJ, Julia J, Lozano C, et al. (2005) Procyanidin fractions from pine (Pinus pinaster) bark: radical scavenging power in solution, antioxidant activity in emulsion, and antiproliferative effect in melanoma cells. J Agric Food Chem 53: 4728-4735.

53. Bocalandro C, Sanhueza V, Gomez-Caravaca AM, Gonzalez-Alvarez J, Fernandez K, Roeckel M, Rodriguez-Estrada MT (2012) Comparison of the composition of Pinus radiata bark extracts obtained at bench- and pilot-scales Ind Crops Prod 38: 21-26.

54. Varma SD, Mizuno A, Kinoshita JH (1977) Diabetic cataracts and flavonoids Science 195: 205-206.

55. Packer L, Rimbach G, Virgili F (1999) Antioxidant activity and biologic properties of a procyanidin-rich extract from pine (Pinus maritima) bark, pycnogenol. Free Radical Biology \& Medicine 27: 704-724.

56. Markham KR (1982) Techniques of Flavonoid Identification. Academic Press London-New York-Paris, Chap 3.

57. Czochanska Z, Foo LY, Newman RH, Porter LJ (1980) Polymeric proanthocyanidins Stereochemistry, structural units and molecular weight. $J$ Chem Soc Perkin Trans 1: 2278-2286.

58. Zhang LL, Lin YM, Zhou HC, Wei SD, Chen JH (2010) Condensed tannins from mangrove species Kandelia candel and Rhizophora mangle and their antioxidant activity. Molecules 15: 420-431.

59. Davis AL, Cai Y, Davies AP, Lewis JR (1996) ${ }^{1} \mathrm{H}$ and ${ }^{13} \mathrm{C}$ NMR assignments of some green tea polyphenols. Magnet Reson Chem 34: 887-890.

60. Waver I, Wolniak M, Paradowska K (2006) Solid state NMR study of dietary fiber powders from aronia, bilberry, black currant and apple. Solid State Nucl Magnet Reson 30: 106-113.

61. Cui CB, Tezuka Y, Kikuchi T, Nakano H, Tamaoki T, et al. (1992) Constituents of a fern, Davallia mariesii Moore II: identification and ${ }^{1} \mathrm{H}$ - and ${ }^{13} \mathrm{C}$-nuclear magnetic resonance spectra of procyanidin B-5, epicatechin-(4 beta-8)epicatechin-(4 beta-6)-epicatechin, and epicatechin-(4 beta-6)-epicatechin-(4 beta-8)-epicatechin-(4 beta-6)-epicatechin. Chem Pharm Bull 40: 889-898.

62. Ricci A, Parpinello GP, Palma AS, Teslić N, Brilli C, et al. (2017) Analytical profiling of food-grade extracts from grape (Vitis vinifera $\mathrm{sp}$ ) seeds and skins green tea (Camellia Sinensis) leaves and Limousin oak (Quercus robur) heartwood using MALDI-TOF-MS, ICP-MS and spectrophotometric methods. Journal of Food Composition and Analysis 59: 95-104. 